\title{
Oxytocin and milk removal: two important sources of variation in milk production and milk quality during and between milkings
}

\author{
Vanessa LOLLIVIER ${ }^{\mathrm{a} *}$, Jocelyne GUINARD-FLAMENT ${ }^{\mathrm{a}}$, \\ Michèle OLLIVIER-BOusqueT ${ }^{\mathrm{b}}$, Pierre-Guy MARNET ${ }^{\mathrm{a}}$
}
${ }^{a}$ UMR INRA/ENSAR Production du Lait, 65 rue de Saint Brieuc, 35000 Rennes, France
b INRA Biologie des Transports Cellulaires, Unité Biologie Cellulaire et Moléculaire, 78352 Jouy-en-Josas, France

\begin{abstract}
This review describes the effects of milking (routine and management) on milk yield and milk quality on dairy ruminants and examines the physiological effects of milking on the synthesis and secretion of milk. During milking, differences in the composition of milk as a result of milk ejection reflex are observed: the cisternal milk, immediately available, contains little fat, then milk ejection provokes active transport of high-fat content alveolar milk, into the cisternal compartment. Milking frequency has the capacity to affect milk production too. So, an increase in milking frequency augments milk yield whereas a decrease in milking frequency decreases milk production, with effects on milk composition. The milk ejection reflex is mediated by oxytocin, which induces myoepithelial cell contraction. Nevertheless, other actions of oxytocin may exist, such as a direct effect on proliferation and differentiation of myoepithelial cells and on secretory processes in the mammary epithelial cells.
\end{abstract}

milking / milk ejection / oxytocin / physiological effects / milk quantity and quality

Résumé - Ocytocine et vidange mammaire : deux facteurs de variation essentiels de la quantité et la qualité du lait pendant la traite et entre les traites. Cette revue bibliographique présente les effets de la traite (technique et conduite) sur la production quantitative et qualitative de lait, puis précise les mécanismes d'action des effets physiologiques de la traite sur la synthèse et la sécrétion des composants du lait. Au cours d'une traite, la composition du lait évolue, grâce au réflexe d'éjection du lait qui provoque le transfert du lait alvéolaire, riche en matières grasses, vers la citerne. Ainsi, le lait de début de traite est pauvre en matière grasse, tandis que le lait de fin de traite est riche en matière grasse. Les rythmes de traite ont aussi un impact sur la production laitière. Ainsi, l'accroissement de la fréquence de traite augmente la production laitière alors que la réduction du nombre de traite la diminue, avec des répercussions en terme de qualité du lait. L'hormone responsable de l'éjection du lait, l'ocytocine, exerce son rôle de vidange mammaire par déclenchement de la

\footnotetext{
* Correspondence and reprints

E-mail: lollivie@roazhon.inra.fr
} 
contraction des cellules myoépithéliales. Cependant, d'autres effets sont envisagés avec notamment un effet direct de l'ocytocine sur la prolifération et la différentiation des cellules myoépithéliales et épithéliales et sur les processus sécrétoires des cellules épithéliales.

traite / éjection du lait / ocytocine / effets physiologiques / quantité et qualité du lait

\section{INTRODUCTION}

The agricultural sectors of Europe, with its traditional twice daily milking, and of North America, with its intensive management and milking practices of three milkings per day, are attempting to improve their management systems in order to be more economical and thus more efficient. Because one of the priorities for dairy farmers is to reduce labor input, management techniques which involve longer milking intervals and perhaps omission of one or more milkings per week, are now being considered. On the contrary, some dairy producers are experimenting with the use of automatic milking systems (robotic milking) in an effort to maximize the milk production potential by allowing their animals to be milked up to six times per day, at their convenience. Therefore, it is now a priority for dairy farmers, milk manufacturers and ultimately consumers to evaluate the consequences that these different management techniques may have on milk production and quality and to understand how the mammary gland responds to either less or more frequent milking.

Ruminants, as well as all other mammals, are capable of modifying mammary development and thus milk production, in accordance with the number of offspring "in utero" [63]. However, it is still unclear how the ruminant mammary gland is able to modify milk production during an established lactation as a result of changes in the environment or management technique. Milk production has been shown to increase in response to increased frequency of suckling and/or number of offspring [16, 56, 60,
85]. Conversely, milk production decreases in response to incomplete milking [59], if the milk ejection reflex and oxytocin release are disturbed [10], and/or if the milking interval is too long. Furthermore, failure to completely remove milk from one quarter of the mammary gland in dairy cattle will lead to drying off of that gland; however, the remaining three glands continue to lactate normally [98].

It is thus quite clear that proper stimulation of the mammary gland, and complete milk ejection and removal to avoid milk stagnation within the gland, involve both systemic and local factors that are essential for regulating and maintaining milk production. The objectives of this review are to describe the effects of different management systems and milking routines on the variation observed in milk production and milk quality of dairy ruminants. This review will emphasize the role of oxytocin, the hormone of milk ejection, in order to describe how oxytocin affects lactation performances of dairy ruminants and to understand the importance of milk removal and conversely, milk stagnation, on the mechanisms, which regulate synthesis and secretion of the different milk components.

\section{EFFECTS OF MANAGEMENT SYSTEM AND MILKING ROUTINE ON MILK PRODUCTION}

\subsection{Milk removal during milking and milk quality}

The mammary gland possesses an internal anatomy which is shared by all ruminants and includes secretory tissue (alveoli) located 
more centrally, and milk storage areas (gland cistern) located more peripherally and ventrally. During machine milking, the cisternal milk is immediately available and can be obtained independently of an active milk ejection; cisternal milk represents approximately $20 \%$ of the total milk volume in dairy cows after a normal 12 hours milking interval [78], and between 50 and $80 \%$ in dairy ewes $[62,66]$ and goats $[62]$. In contrast, the alveolar milk, which remains fixed in the mammary gland by capillary forces and by the presence of sphincters in the small intralobular ducts [104], is only obtained when active expulsion of milk occurs during the oxytocinmediated milk ejection reflex [26].

The milk ejection reflex occurs as a result of nervous stimulation at the level of the teat and mammary gland by either the suckling young or the milking machine, followed by transmission of nerve impulses through the mammary gland and spinal cord, which finally reach the supraoptic and paraventricular nuclei within the hypothalamus. Stimulation of these hypothalamic nuclei provokes a release of oxytocin from its storage site in magnocellular neurons that extend into the neurohypophysis and through the posterior pituitary into the systemic circulation (see review [95]). In dairy cows, during the first 2 minutes following application of the teat cups, plasma oxytocin concentrations rise, and then slowly decline, reaching basal oxytocin concentrations between 10 and 15 minutes (Fig. 1).
Oxytocin is transported by the systemic circulation to the mammary gland where it binds to its specific membrane receptor located on mammary myoepithelial cells, which surround the alveoli and small intralobular ductules. Myoepithelial contraction causes flattening of the alveolar lumen, and thus milk is transferred through the ductules in the direction of the cistern and teat for eventual milk removal.

Milk ejection is an essential component for complete milk removal during machine milking. When milk ejection is inhibited, for example by anesthesia [55], by environmental disturbances due to milking in unfamiliar surroundings [10], or by injection of oxytocin receptor antagonists such as Atosiban $[12,67]$, milk removal is not complete and as a result milk yields are decreased, which proves the importance of oxytocin for optimal milk removal. This importance was confirmed by the invalidation of the oxytocin gene $[69,103]$. Although even weak increases of oxytocin concentrations are sufficient to elicit milk ejection [11, 84], continuously elevated concentrations throughout the milking process are required for efficient milk removal in dairy cattle [11]. Such continuously high concentrations of endogenous oxytocin release during machine milking optimize milk removal by preventing myoepithelial relaxation and therefore help to inhibit milk from returning to the alveoli and small ductules.
Figure 1. Plasma oxytocin profiles in a dairy cow in mid-lactation during milking.

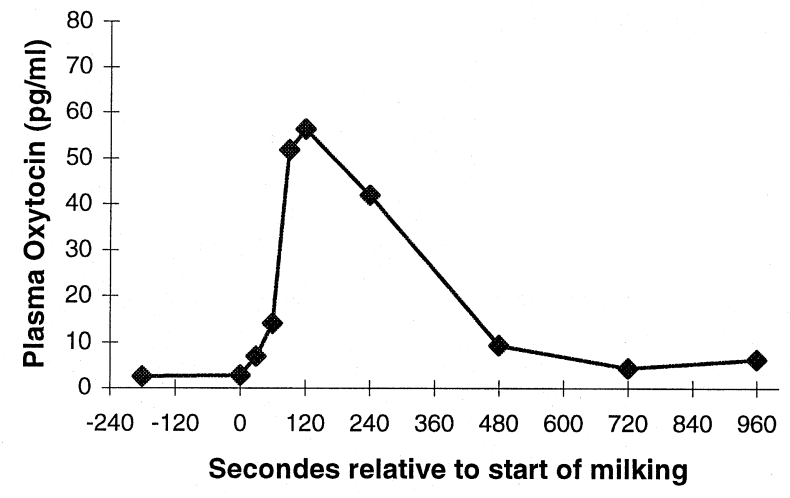




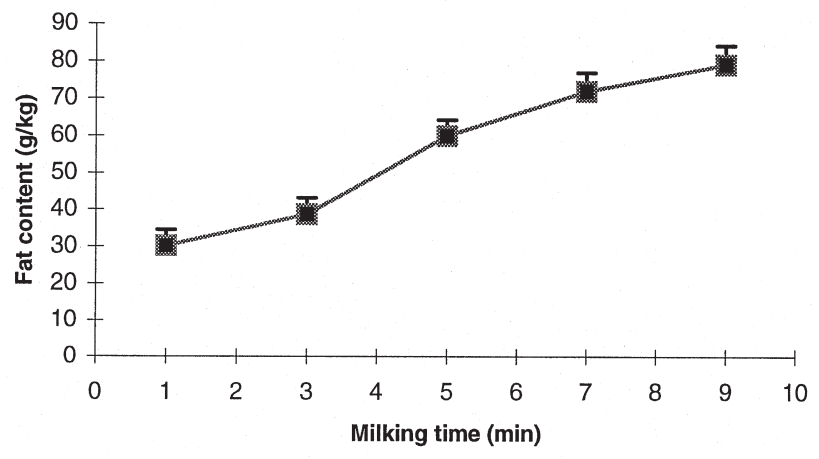

Figure 2. Evolution of milk fat content during milking in dairy cows [36].
Moreover, the milk ejection reflex has a significant effect on the quality of milk obtained during milking. During machine milking, the concentration of milk fat increases with time; milk removed at the beginning of a milking, corresponding to the cisternal milk, is less rich in milk fat than milk removed at the end of a single milking, corresponding to the alveolar milk ( 2.5 to 5 times more rich in milk fat compared to the cisternal milk) (Fig. 2). Indeed, milk fat globules are transferred from the alveoli to the cistern during machine milking as a result of oxytocin-mediated milk ejection [36, 43]. Conversely, removal of milk protein and lactose is rather consistent during a single machine milking.

\subsection{Effect of interval between milkings}

Since efficient milk ejection is essential to ensure complete milk removal and sustain milk secretion, milking intervals are also determinant with regards to lactational performances. In general, dairy cows are milked twice per day with milking intervals varying between 12:12 and 8:16 hours. Much research has been devoted to determine an appropriate milking routine, which maximizes milk production yet minimizes labor input. In high producing dairy cattle, a milking interval of 12:12 hours improved milk yield by about 3 to $5 \%$ compared to a milking interval of 10:14 hours [30], suggesting that milk secretion might be inhibited when the milking interval is too long. Some studies have attempted to delineate the maximum milking interval without inducing a loss in milk production. As a result, some authors have reported that down-regulation of milk secretion begins 10 hours after milking whereas others have observed longer intervals (16 hours after milking) [25, 104]. Such discrepancies might depend on individual animal variations $[25$, $66,104]$ and may be partly linked to the anatomical characteristics of the udder. The ability of an animal to withstand longer intervals between milkings could be related to their larger cisternal volume of milk. Such an observation is particularly true with species having large cisterns as in dairy ewes [62] and this has also been reported for dairy cows [52]. Indeed, dairy cows with large cisterns are more persistent and produce more milk than cows with small cisterns.

Additionally, milk composition shows diurnal variations. Milk from evening milkings is more rich, both in fat and protein (5-8 $\mathrm{g} \cdot \mathrm{L}^{-1}$ and $2 \mathrm{~g} \cdot \mathrm{L}^{-1}$, respectively) than milk from morning milkings (see review [53]). This is probably due to an unequal interval between the milkings: milk from morning milkings is collected after a long interval. Fat globules, which are trapped in the alveoli, are not totally transferred along the mammary ducts before the end of the morning milking and are only delivered at the evening milking. 


\subsubsection{Lengthening the milking interval}

According to Stelwagen et al. [88], milking intervals should not exceed 18 hours in order to avoid any deleterious effects on milk yield and/or quality. However, milking routines of mid-lactation dairy cows with consecutive intervals of 14,16 and 18 hours (i.e., three milkings every two days) result in a $16 \%$ reduction in milk yield with no change in milk composition [80].

Lengthening the milking interval up to 24 hours leads to a decrease in milk yield of about 10 to $50 \%$ in dairy cows (see review [19]). Short-term research trials (one week) with mid-lactation Friesian and Jersey dairy cows has demonstrated that once-daily milking reduces milk production by 10 to $25 \%[14,52]$. Responses to once-daily milking are a function of the stage of lactation because a decrease in milk production is more pronounced for animals in early lactation compared to late lactation ( -38 vs. $-28 \%$, respectively, [87]). With long-term research trials (the entire lactation), oncedaily milking results in production losses of approximately $50 \%$ [15] and 35\% with high individual variations (from 10 to $50 \%$ ) [40].

With regards to milk composition, intervals longer than 16 hours may lead to variations in fat content in dairy cows ([80], see review [104]). On the contrary, in mid- and late-lactation dairy ewes, a 16 hour milking interval has no effect on milk composition as compared to ewes milked every 12 hours [66]. In contrast, passage from twice daily milkings to once daily milkings is generally accompanied by an increase in milk contents of fat, protein, sodium, chloride and somatic cell count, and a decrease in lactose and potassium (see review [19]).

\subsubsection{Decreasing the milking interval}

Three-daily milkings results in an improvement in milk production of 3 to 39\% compared to twice-daily milkings in dairy cows (see review [4]). This effect is more marked in high-producing dairy cows $(+9.2 \%$ in cows with daily production levels of 26 to $34 \mathrm{~kg}$, compared to $+23.8 \%$ in cows with $>34 \mathrm{~kg}$, [91]). Furthermore, this effect is in relation to lactation number: some studies indicate that primiparous cows benefit the most from more frequent milkings (19.4, $13.5,11.7$, and $13.4 \%$ increase in milk production for cows in their first through fourth lactation, respectively, $[2,6])$, whereas one report concludes that the effect is more beneficial in multiparous cows ( +15 vs. $+6 \%$ increase, for multiparous and primiparous cows, respectively, [21]). Increased milk production associated with more frequent milkings appears to be more important for animals at the end of lactation [77] than at the beginning [76] ( +16 to $90 \%$ vs. +7 to $12 \%$ increase at the end or beginning of lactation, respectively). The acquired effect of more frequent milking on increased milk production is rapid and is consistently maintained throughout the period of more frequent milkings $[38,76]$, and perhaps even after returning to twice daily milkings [7]. Finally, lactation persistency is increased in dairy goats that are milked more frequently [49]; this effect also appears to be plausible for lactation persistency in dairy cows [38].

The effect of three-daily milkings has been shown to either have no significant effect on milk composition $[3,21]$ or a slight yet significant reduction in milk fat concentration $(-0.15$ percentage units) compared to twice-daily milkings [6], with the reduction being more important for primiparous, compared to second parity dairy cows ( -0.32 vs. -0.23 percentage units, respectively, [91]). Conversely, there is at least one report that the reduction in the percentage of milk fat in three-daily milked dairy cows is lower for multiparous than primiparous animals $(-0.10$ vs. -0.06 percentage units, respectively [2]). Over the entire lactation, there does not appear to be an effect on milk protein concentration due to an increased milking frequency $[13,91]$. 
However, this is in contrast to one report, which demonstrated a lower percentage of milk protein and casein content in cows milked thrice-, compared to twice-daily $(-0.085$ percentage units lower) [47].

Work done with robotic milking of dairy cows (otherwise known as an automatic milking system or AMS) demonstrated that cows voluntarily presented themselves to the AMS for milking an average of 3.9 times per day [42], which could indicate a preference of dairy cows in accordance with their behavior and physiology. Interestingly, when the milking interval for dairy cows in the milking parlor is increased to four times per day for a period of 4 weeks, milk production increases between 10.4 and $14 \%$ [38]. However, increasing the milking frequency to 6 times per day does not further augment milk production (10.7\%) [94]. Thus, there does not appear to be any advantage to increasing the milking frequency beyond 3 to 4 times per day in dairy cows [86] and in dairy ewes [68].

\section{EFFECTS OF EXOGENOUS OXYTOCIN ADMINISTRATION ON MILK PRODUCTION}

Milking is a source of variation in determining milk yield and milk quality and one of the major events of milking is the oxytocin-mediated ejection reflex. Then, we focus on oxytocin in order to examine how this hormone acts on milk yield and composition.

Although there are numerous reports that exogenous oxytocin administration at the time of machine milking can increase milk production, there are contradictions in the literature with respect to its effect on milk production and milk quality. These are primarily due to differences in methodology and experimental design between researchers: for example in the number of animals, length of experimentation, stage of lactation, injection followed by milk removal or not, injection given to animals with full or empty udders, and dose of oxytocin administered. Milk ejection is elicited with 0.1 I.U. of oxytocin [82], and complete milk removal is obtained following intravenous injection of 0.5 to 1 I.U. in dairy cows [54], and with 0.1 to 1 I.U. in dairy goats [64]. Nevertheless, in most of the reports, researchers used nonphysiologic (10 or 20 I.U.) doses or even extraphysiologic doses of oxytocin (40 I.U.). It would thus appear necessary to better delineate the effects of physiologic concentrations of oxytocin on milk production.

Small doses of oxytocin (0.02 to 0.3 I.U.) administered over a short period ( $2 \mathrm{~d}$ ) prior to milking result in either a significant increase in milk production $[33,34]$ or no change in milk yield, but induce an increase in milk flow rate and a shorter machine milking time [82]. According to Knight [48], administration of large quantities of oxytocin (20 I.U.) over one week resulted in an increase in milk production of $15.5 \%$ only if each milking was followed by complete milk removal from the udder. Conversely, when oxytocin (20 I.U.) was administered to dairy cows over a couple of weeks, either before or after milking, milk production increased by $3 \%$, regardless of the time of injection [5]. However, another more longterm study demonstrated that oxytocin injection (20 I.U.) prior to each milking for the entire lactation increased milk production by $11.6 \%$; most of the increase in milk yield occurred during the descending phase of lactation [71].

Some authors would claim that there is no modification of milk composition (milk fat, protein, lactose, somatic cell count, or plasmin activity) regardless if oxytocin is administered over medium or long periods of time $[5,71]$. However, oxytocin administration was shown to significantly modify milk quality proportionally to dose: increasing doses (0.1 to 3 I.U.) results in increases in milk fat, but concurrent doses results in decreases in milk protein $[31,82]$. Additionally, massive doses of oxytocin (40 I.U. 
every $20 \mathrm{~min}$ for $80 \mathrm{~min}$ following milking) reduce milk fat content without affecting milk fatty acid composition [22]. Finally, oxytocin administration could have a negative effect on milk fat content, by retaining milk fat within the alveolar compartment. Actually, two injections of 10 I.U. of oxytocin, without milk removal, significantly increase fat globule diameter by $0.22 \mu \mathrm{m}$ (4.25 to $4.47 \mu \mathrm{m})$. In fact, the resulting increase in intra-mammary pressure might induce fat globule coalescence [36].

\section{PHYSIOLOGIC EFFECTS OF MILKING ON THE SYNTHESIS AND SECRETION OF MILK}

\subsection{Effect of milk removal}

The mammary gland, although physiologically considered a powerful machine, is constantly faced with the juxtaposition of producing sufficient amounts of milk (originally destined for nutrition of the young), yet adequately ridding itself of this milk in order to avoid the negative effects of milk stagnation on milk synthesis and on the eventual involution of the gland. In order to not over-produce, which would be a waste of valuable nutrition that could be used for other life processes (reproduction, for example), the mammary gland is equipped with an auto-regulatory mechanism for the control of milk synthesis. Frequent and complete milk removal reduces the negative effect of this self-regulatory mechanism on milk secretion. This mechanism has been associated to the co-secretion of a glycoprotein in milk, which might have the ability to exert negative feedback locally on milk protein and lactose synthesis. This glycoprotein (known as the Feedback Inhibitor of Lactation, FIL) and its effects was first described in the goat [102], because of its ability to reduce the rate of milk secretion in vitro $[99,101]$ and in vivo [100] when it is in contact with the alveolar epithelium [74]. FIL might reversibly block the constitutive pathway of milk protein biosynthesis (specifically the transport between the endoplasmic reticulum and the Golgi apparatus, as well as intra-Golgi transport) in mammary epithelial cells, resulting in the inhibition of casein and lactose synthesis, as well as the stimulation of the intracellular degradation of newly synthesized casein [101]. In addition, FIL might regulate the size of the secretory cell population, in part by triggering apoptosis in the mammary gland [79], and/or by reducing the sensitivity of mammary epithelial cells to galactopoietic hormones, such as prolactin, by reducing the number of prolactin receptors [8]. A reduction in prolactin receptors is thought to reduce the normal anti-apoptotic properties of prolactin [28, 92, 93]. Finally, when machine milking is incomplete, or when the daily number of milkings is reduced, it is believed that the accumulation of FIL within the alveoli increases, which leads to reduced milk synthesis as described above.

Alternatively, one could also envisage that more frequent udder evacuation and milk removal would not only reduce accumulation of FIL, but would also avoid any deleterious effects of increased intra-alveolar pressure on milk synthesis. Indeed, in dairy goats it has been shown that after 21 hours of milk accumulation, the resulting increased intra-mammary pressure provokes a destruction of alveolar secretory epithelium via tight junction rupture. Tight junctions begin to become leaky after 18 to 20 hours of udder filling [87], which coincides directly with the beginning of a decrease in the milk secretion rate in dairy goats [89] and cows [18]. This rupture results in a significant modification of the ionic composition of milk, with an increase in milk lactose, sodium, and chloride and a decrease in milk potassium [89]. Physiological increases of intra-mammary pressure causes compression of mammary secretory epithelia, resulting in accompanying mechanical changes within the alveoli including perturbation of the cytoskeleton [70] and 
mechanotransduction effects on gene expression $[19,86]$, which all interfere with milk secretion and could lead to apoptosis. Additionally, high intra-mammary pressure between milkings reduces mammary blood flow by $10 \%$ after 24 hours of udder filling in dairy cows [35] and by $50 \%$ after 36 hours in dairy goats [89], which at the same time reduces the supply of nutrition and hormones to the udder and then reduces the rate of milk secretion [32, 73, 75]. Alternatively, milk removal from the gland during machine milking improves mammary blood flow in dairy cows [41] and in dairy goats [81].

\subsection{Systemic effects}

Stimulation of the mammary gland during nursing and machine milking is of great benefit to the gland due to the release of several lactogenic hormones from the pituitary. Prolactin [44] favors the synthesis and secretion of the milk components, and also influences fat metabolism within mammary adipose tissue. Adrenocorticotrophin hormone $(\mathrm{ACTH})$, which is also released during milking [20], participates in conjunction with the glucocorticoids in maintaining lactation via its general effects on metabolism, by markedly amplifying the gland's response to prolactin [39]. It was originally suggested that growth hormone $(\mathrm{GH})$ is released during milking in goats [37]. This has not been confirmed for goats [50] nor for cows [51], and the simultaneous effect of administration of $\mathrm{GH}$ and increasing the milking frequency is additive; this indicates that these two galactopoietic stimuli operate by independent mechanisms.

Increased milking frequency could assure a better hormonal maintenance of lactation simply as a result of increased stimulation of hormonal release, and thus more metabolic and synthetic activity within the mammary gland. These hormones, in addition to their metabolic effects, could improve the number of secretory cells and thus increase the vol- ume of milk secreted [29, 45, 49]. In ruminants, the number of secretory cells slowly decreases throughout the course of an established lactation via apoptotic mechanisms [79], without modification of the secretory activities of the remaining cells [49]. The diminution in the number of secretory cells is not pre-determined and instead can be modified by milking frequency [58]; increasing the number of daily milkings results in cellular hypertrophy, which is followed by proliferation of new secretory cells and then an increase in secretory cell number. This permits an increase in lactation persistency with little, if any, effect on milk composition [38].

Machine milking or nursing, as indicated previously in this review, is the principal stimulus responsible for the release of oxytocin from the posterior pituitary, and for the subsequent oxytocin-mediated myoepithelial contraction for milk removal. For many years this reflex has been considered the only mechanism within the mammary gland capable of eliciting milk ejection. Pituitary oxytocin is thus generally considered as the only hormone capable of increasing milk production via stimulation of the milk ejection reflex $[1,9,23,31,48]$. In addition to neurohypophyseal release of oxytocin during machine milking, oxytocin is synthesized, stored, and released by the corpus luteum [90, 96, 97], which is continual and repetitive during an estrous season, yet independent of lactation. This luteal oxytocin may also participate in facilitating milk removal by its influence on milk transfer from the alveoli to the cistern between milkings $[57,65]$.

In brief, for most authors, the increase in milk production associated with the injection of oxytocin can only be explained by a mechanical action of oxytocin as a result of myoepithelial contraction and thus expulsion of the synthesized milk products from the alveoli [17], thereby limiting the negative effects of FIL or increased intra-alveolar pressure on milk secretion. 
The galactopoietic action of oxytocin could also be explained by direct stimulation of mammary blood flow [27], probably as a result of the vasopressin-like effect of oxytocin, which would augment the supply of nutrients and lactogenic hormones to the gland.

Yet another possibility exists: oxytocin may exert a direct effect on the epithelial cell. For instance, Nostrand [71] demonstrated that long-term daily injections of oxytocin in dairy cows resulted in an increase in milk production, particularly during the descending phase of lactation. These results might be explained by a galactopoietic effect of oxytocin, as is the case for antiapoptotic prolactin, permitting a more persistent lactation. Moreover, oxytocin may act on mammary cells by inducing cell differentiation and proliferation as was shown in the nonlactating mouse mammary gland [83]. Finally, a direct galactopoietic effect of oxytocin on milk synthesis in the mammary gland may exist, which might explain the increases in milk production [5]. This is to say, that perhaps in addition to the effect of oxytocin on milk ejection and removal, this hormone may exert direct effects on secretory epithelial cells and thus stimulate their secretion. In accordance with this hypothesis, Ollivier-Bousquet [72] demonstrated that in vitro, the addition of oxytocin resulted in the acceleration of intracellular transit of casein as well as in the augmentation of its secretion in lactating rabbit mammary fragments. Increases in the secretion rate of casein were not simply due to a mechanical effect of myoepithelial contraction, because intracellular transport of nascent protein between the endoplasmic reticulum, Golgi apparatus, and secretory vesicles (stages which all require an active participation from the energetic processes of the cell), was also affected.

Recently, we observed a double effect of oxytocin within lactating mammary tissue, which is consistent not only with its classic role in myoepithelial contraction and alveolar emptying, but also with a direct role in influencing mammary secretory epithelium [61]. More precisely, we demonstrated that oxytocin first provokes a rapid release of casein into the alveolar lumen, which is accompanied by displacement of the two markers, GP58 and annexin II. GP58 is a Golgi membrane protein, which permits monitoring of the early events in the secretory pathway (intracellular transfer of secretory vesicles). Annexin II is part of a family of proteins that enables the in vitro establishment of homotypic connections between secretory vesicle membranes, thereby allowing us to follow the process of exocytosis (final stages of secretion) [24]. Our observations concerning the localization of GP58 and annexin II at the apical end of the cell, also led us to believe that there is an influence of oxytocin during the whole protein secretion process. At the same time, we observed a transfer of fat globules on the apical part of the epithelial cell, as a result of the oxytocin effect. Moreover, we observed specific linkage sites between oxytocin and rabbit mammary epithelial cells, which would confirm a direct cellular action of this hormone. Receptors for oxytocin have already been localized in mammary epithelia in lactating women and marmosets [46], which indicates that oxytocin should have a direct physiologic role in secretory activity. However, the above-mentioned model species are devoid of the cisternal compartment, therefore such an oxytocin receptivity still has to be proven in the ruminant mammary gland.

\section{CONCLUSIONS}

Stimulation of the mammary gland during milking is necessary for the initiation and maintenance of lactation, quite as much as nutrients captured by the gland (Input), and will ultimately affect milk production (Output) via the effect of milk removal and separate systemic effects. The most important factor influencing milk removal and 
evacuation of the gland is the presence of the oxytocin-mediated milk ejection reflex. Oxytocin influences milk production by reducing intra-alveolar pressure, reducing the presence of the feedback inhibitor of lactation from around the alveoli, and reestablishing normal mammary blood flow. Furthermore, the presence of a proper milk ejection reflex during milking is a crucial factor for obtaining alveolar milk that is rich in total solids. In addition to the beneficial effect of oxytocin on milk production and milk quality due to better milk transfer within the mammary gland, oxytocin could also have a direct stimulatory effect on mammary metabolism. In fact, the mechanisms behind the effect of oxytocin on mammary metabolism have only recently been addressed, and merit further research, specifically with the use of physiological concentrations of oxytocin during or without milk removal. If the effect of physiological concentrations of oxytocin is demonstrated, this would confirm our observations concerning its effect on intracellular processes of milk secretion. Thus, it will be particularly useful to further study the regulation of intracellular signaling cascades associated with oxytocin binding of its receptor on secretory mammary epithelial cells.

It is clear that the effects of oxytocin on milk production are numerous, complex, and difficult to quantify at present. Further studies in this area will be achieved at different levels: cell, tissue, and animal, and although the results of this work will no doubt yield copious amounts of information, it will be most interesting to eventually categorize and rank all the possible effects of oxytocin on the mammary gland.

\section{ACKNOWLEDGEMENTS}

The authors would like to thank Dr. Brett McKusick for his help in translating the manuscript.

\section{REFERENCES}

[1] Adams H.P., Allen N.N., The value of oxytocin for reducing fluctuations in milk and fat yield, J. Dairy Sci. 35 (1952) 1117.

[2] Allen D.B., DePeters E.J., Laben R.C., Three times a day milking: effects on milk production, reproductive efficiency, and udder health, J. Dairy Sci. 69 (1986) 1441-1446.

[3] Amos H.E., Kiser T., Loewenstein M., Influence of milking frequency on productive and reproductive efficiencies of dairy cows, J. Dairy Sci. 68 (1985) 732-739.

[4] Armstrong D.V., Milking frequency. Internet communication: www.dairybiz.com/archive/ nutrition-14.htm, 1999.

[5] Ballou L.U., Bleck J.L., Bleck G.T., Bremel R.D., The effects of daily oxytocin injections before and after milking on milk production, milk plasmin, and milk composition, J. Dairy Sci. 76 (1993) 1544-1549.

[6] Barnes M.A., Pearson R.E., Lukes-Wilson A.J., Effects of milking frequency and selection for milk yield on productive efficiency of Holstein cows, J. Dairy Sci. 73 (1990) 1603-1611.

[7] Bar-Peled U., Maltz E., Bruckental I., Folman Y., Kali Y., Gacitua H., Lehrer A.R., Knight C.H., Robinzon B., Voet H., Relationship between frequent milking or suckling in early lactation and milk production of high producing dairy cows, J. Dairy Sci. 78 (1995) 2726-2736.

[8] Bennett C.N., Knight C.H., Wilde C.J., Regulation of mammary prolactin binding by a secreted milk protein, J. Endocrinol. (Suppl.) 127 (1990) 141.

[9] Bremel R.D., Action of oxytocin on mammary myoepithelial cells, in: Proc. Oxytocin: Clin. Lab. Stud., Elsevier Sci. Publ., Amsterdam, 1985 , p. 303.

[10] Bruckmaier R.M., Schams D., Blum J.W., Milk removal in familiar and unfamiliar surroundings: concentrations of oxytocin, prolactin, cortisol and beta-endorphin, J. Dairy Res. 60 (1993) 449-456.

[11] Bruckmaier R.M., Schams D., Blum J.W., Continuously elevated concentrations of oxytocin during milking are necessary for complete milk removal in dairy cows, J. Dairy Res. 61 (1994) 323-334.

[12] Bruckmaier R.M., Wellnitz O., Blum J.W., Inhibition of milk ejection in cows by oxytocin receptor blockade, alpha-adrenergic receptor stimulation and in unfamiliar surroundings, J. Dairy Res. 64 (1997) 315-325.

[13] Campos M.S., Wilcox C.J., Webb D.W., Hayen J., Effects on production of milking three times daily on first lactation Holsteins and Jerseys in Florida, J. Dairy Sci. 77 (1994) 770-773. 
[14] Carruthers V.R., Davis S.R., Copeman P.J., Effects of oxytocin, machine stripping and milking rate on production loss of cows milked once a day, J. Dairy Res. 60 (1993) 13-18.

[15] Claesson O., Hansson A., Gustafsson N., Brannang E., Studies on monozygous cattles twins. XVII. Once-a-day milking compared twice-a-day milking, Acta Agric. Scand. 9 (1959) 38-58.

[16] Cowie A.T., Lactation, in: Austin and Short, Reproduction in Mammals, Book 3: Hormonal control of reproduction, Cambridge University Press, 1984, pp. 228-230.

[17] Da Costa T.H.M., Ilic V., Williamson D.H., In vitro effects on oxytocin and ionomycin on lipid secretion by rat mammary gland, Role of the myoepithelial cells, in: Wilde, Peaker and Knight, Intercellular Signalling in the Mammary Gland, Plenum Press, New-York, 1995, p. 265.

[18] Davis S.R., Farr V.C., Copeman P.J.A., Carruthers V.R., Knight C.H., Stelwagen K., Partitioning of milk accumulation between cisternal and alveolar compartments of the bovine udder: relationship to production loss during once daily milking, J. Dairy Res. 65 (1998) 1-8.

[19] Davis S.R., Farr V.C., Stelwagen K., Regulation of yield loss and milk composition during once-daily milking: a review, Livest. Prod. Sci. 59 (1999) 77-94.

[20] Denamur R., The hypothalamo-neurohypophysial system and the milk ejection reflex, Dairy Sci. Abst. 27 (1965) 193-254.

[21] DePeters E.J., Smith N.E., Acedo-Rico J., Three or two times daily milking of older cows and first lactation cows for entire lactations, J. Dairy Sci. 68 (1985) 123-132.

[22] Dill C.W., Lane G.T., Hartsfield S.N., Influence of repeated oxytocic treatments on composition of bovine milk fat, J. Dairy Sci. 57 (1974) 1164-1169.

[23] Donker J.D., Koshi J.H., Petersen W.E., The effects of hourly milking with the aid of intravenous injection of oxytocin, J. Dairy Sci. 37 (1954) 1261

[24] Donnelly S.R., Moss S.E., Annexins in the secretory pathway, Cell Mol. Life Sci. 53 (1997) 533-538.

[25] Elliott G.M., The direct effect of milk accumulation in the udder of the dairy cow upon milk secretion rate, Dairy Sci. Abstr. 21 (1959) 435-439.

[26] Ely F., Petersen W.E., Factors involved in the ejection of milk, J. Dairy Sci. 24 (1941) 211-223.

[27] Fleet I.R., Davis A.J., Richardson M., Heap R.B., The stimulation of mammary blood flow by oxytocin and the potential role of locally released nitric oxide in the goat, J. Reprod. Fertil. 11 (1993) 104.
[28] Flint D.J., Knight C.H., Interactions of prolactin and growth hormone $(\mathrm{GH})$ in the regulation of mammary gland function and epithelial cell survival, J. Mammary Gland Biol. Neoplasia 2 (1997) 41-48.

[29] Fowler P.A., Knight C.H., Cameron G.G., Foster M.A., In-vivo studies of mammary development in the goat using magnetic resonance imaging (MRI), J. Reprod. Fertil. 89 (1990) 367-375.

[30] Galton D.M., Merrill W.G., Maximizing milk secretion through management, Internet Communication: www.inform.umd.edu/EdRes/ Topic/Agr, 1998.

[31] Gorewit R.C., Sagi R., Effects of exogenous oxytocin on production and milking variables of cows, J. Dairy Sci. 67 (1984) 2050-2054.

[32] Graf G.C., Factors affecting intramammary pressures, J. Dairy Sci. 51 (1968) 1672-1675.

[33] Graf G.C., Ejection of milk in relation to levels of oxytocin injected intramuscularly, J. Dairy Sci. 52 (1969) 1003-1007.

[34] Graf G.C., Ejection of milk in relation to oxytocin injected intravenously, J. Dairy Sci. 53 (1970) 1283-1285.

[35] Guinard-Flament J., Rulquin H., Effect of once daily milking on mammary blood flow (MBF) in dairy cows, Livest. Prod. Sci. 70 (2001) 180.

[36] Guinard-Flament J., Michalski M.C., Rulquin H., Evolution of milk fat content and fat globule diameter according to milking time in dairy cows. Rencontres Recherches Ruminants 2001, Paris, France.

[37] Hart I.C., Flux D.S., The release of growth hormone in response to milking in the goat during early and late lactation, J. Endocrinol. 57 (1973) 177-178.

[38] Hillerton J.E., Knight C.H., Turvey A., Wheatley S.D., Wilde C.J., Milk yield and mammary function in dairy cows milked four times daily, J. Dairy Res. 57 (1990) 285-294.

[39] Hobbs A.A., Richard D.A., Kessler D.J., Rosen J.M., Complex hormonal regulation of rat casein gene expression, J. Biol. Chem. 257 (1982) 3598-3605.

[40] Holmes C.W., Wilson G.F., MacKenzie D.D.S., The effects of milking once daily throughout lactation on the performance of dairy cows grazing on pasture, in: Proceedings, N.Z. Soc. Anim. Prod. 52 (1992) 13-16.

[41] Houvenaghel A., Peeters G., Verschooten F., Influences of manual udder stimulation and oxytocin on mammary artery blood flow in lactating cows, Arch. Int. Pharmacodyn. Ther. 205 (1973) 124-133.

[42] Ipema A.H., Benders E., Production, duration of machine-milking and teat quality of dairy cows milked 2, 3 or 4 times daily with variable intervals, in: Prospects for Automatic Milking, Pudoc Scientific Pub., Wageningen, 1992, pp. 244-252. 
[43] Johannsson I., Studies on udder evacuation in dairy cows. II. The amount and composition of the residual milk after normal milkings, Acta Agric. Scand. 2 (1952) 22-36.

[44] Kann G., Habert R., Meusnier C., Ryniewicz H.S., Prolactin release in response to nursing or milking stimulus in the ewe. Is it mediated by thyrotrophin releasing hormone?, Ann. Biol. Anim., Biochim. Biophys. 17 (1977) 441-452.

[45] Keys J.E., Capuco A.V., Akers R.M., Djiane J., Comparative study of mammary gland development and differentiation between beef and dairy heifers, Domest. Anim. Endocrinol. 6 (1989) 311-319.

[46] Kimura T., Ito Y., Einspanier A., Tohya K., Nobunaga T., Tokugawa Y., Takemura M., Kubota Y., Ivell R., Matsuura N., Saji F., Murata Y., Expression and immunolocalization of the oxytocin receptor in human lactating and nonlactating mammary glands, Hum. Reprod. 13 (1998) 2645-2653.

[47] Klei L.R., Lynch J.M., Barbano D.M., Oltenacu P.A., Lednor A.J., Bandler D.K., Influence of milking three times a day on milk quality, J. Dairy Sci. 80 (1997) 427-436.

[48] Knight C.H., Short-term oxytocin treatment increases bovine milk yield by enhancing milk removal without any direct action on mammary metabolism, J. Endocrinol. 142 (1994) 471-473.

[49] Knight C.H., Mammary cell changes during pregnancy and lactation, Livest. Prod. Sci. 35 (1993) 3-19.

[50] Knight C.H., Fowler P.A., Wilde C.J., Galactopoietic and mammogenic effects of long-term treatment with bovine growth hormone and thrice daily milking in goats, J. Endocrinol. 127 (1990) 129-138.

[51] Knight C.H., Hillerton J.E., Kerr M.A., Teverson R.M., Turvey A., Wilde C.J., Separate and additive stimulation of bovine milk yield by the local and systemic galactopoietic stimuli of frequent milking and growth hormone, J. Dairy Res. 59 (1992) 243-252.

[52] Knight C.H., Dewhurst R.J., Once daily milking of dairy cows: relationship between yield loss and cisternal milk storage, J. Dairy Res. 61 (1994) 441-449.

[53] Labussière J., Composition du lait et techniques de traite chez quelques espèces domestiques, Bull. Tech. C.R.Z.V. 61 (1985) 49-58.

[54] Labussière J., Ricordeau G., Aptitude à la traite mécanique des brebis de race Préalpes du Sud et croisées Frison $\times$ Préalpes. Étude à différents stades de la lactation, Ann. Zootech. 19 (1970) 159-190.

[55] Labussière J., Martinet J., Denamur R., The influence of the milk ejection reflex on the flow rate during the milking of ewes, J. Dairy Res. 36 (1969) 191-200.
[56] Labussière J., Combaud J.F, Pétrequin P., Influence de la fréquence des traites et des tétées sur la production laitière des brebis Préalpes du Sud, Ann. Zootech. 23 (1974) 445-457.

[57] Labussière J., Marnet P.G., Combaud J.F., Beaufils M., de la Chevalerie F.A., Influence of the number of corpora lutea on the release of luteal oxytocin, the transfer of alveolar milk to the cistern and milk production in the ewe, Reprod. Nutr. Dev. 33 (1993) 383-393.

[58] Li P., Rudland P.S., Fernig D.G., Finch L.M., Wilde C.J., Modulation of mammary development and programmed cell death by the frequency of milk removal in lactating goats, J. Physiol. (Lond.) 519 (1999) 885-900.

[59] Linzell J.L., Peaker M., The effects of oxytocin and milk removal on milk secretion in the goat, J. Physiol. (Lond.) 216 (1971) 717-734.

[60] Loerch S.C., McClure K.E., Parker C.F., Effects of number of lambs suckled and supplemental protein source on lactating ewe performance, J. Anim. Sci. 60 (1985) 6-13.

[61] Lollivier V., Rainteau D., Marnet P.G., Letort S., Delpal S., Ollivier-Bousquet M., Early oxytocin effects on secretory events in rabbit and cow mammary cells, Livest. Prod. Sci. 70 (2001) 180.

[62] Marnet P.G., McKusick B.C., Regulation of milk ejection and milkability in small ruminants, Livest. Prod. Sci. 70 (2001) 125-133.

[63] Martal J., Chene N., Placenta et lactation, in: Biologie de la lactation, Martinet et Houdebine, INSERM/INRA (Ed.), Paris, 1993, pp. 31-54.

[64] Martinet J., Denamur R., Étude préliminaire des mécanismes de l'évacuation du lait de la glande mammaire chez la chèvre et la brebis, Arch. Sci. Physiol. 14 (1960) 35-96.

[65] McKusick B.C., Wiltbank M.C., Sartori R., Marnet P.G., Thomas D.L., Effect of presence or absence of corpora lutea on milk production in East Friesian dairy ewes, J. Dairy Sci. 85 (2002) 790-796.

[66] McKusick B.C., Thomas D.L., Berger Y.M., Marnet P.G., Effect of milking interval on alveolar versus cisternal milk accumulation and milk production and composition in dairy ewes, J. Dairy Sci. (in press).

[67] McKusick B.C., Thomas D.L., Romero J.L., Marnet P.G., Effect of weaning system on milk composition and distribution of milk fat within the udder of East Friesian dairy ewes, J. Dairy Sci. (in press).

[68] Negrao J.A., Marnet P.G., Labussière J., Effect of milking frequency on oxytocin release and milk production in dairy ewes, Small Ruminants Res. (2001) 181-187.

[69] Nishimori K., Young L.J., Guo Q., Wang Z., Insel T.R., Matzuk M.M., Oxytocin is required for nursing but not essential for parturition or reproductive behaviour, Proc. Natl. Acad. Sci. USA 93 (1996) 11699-11704. 
[70] Nickerson S.C., Smith J.J., Keenen T.W., Role of microtubules in milk secretion - Action of colchicine on microtubules and exocytosis of secretory vesicles in rat mammary epithelial cells, Cell. Tissue Res. 207 (1980) 361-376.

[71] Nostrand S.D., Galton D.M., Erb H.N., Bauman D.E., Effects of daily exogenous oxytocin on lactation milk yield and composition, J. Dairy Sci. 74 (1991) 2119-2127.

[72] Ollivier-Bousquet M., In vitro effect of oxytocin on intracellular transit and secretion of milk proteins, C.R. Acad. Sci. D 282 (1976) 1433-1436.

[73] Peaker M., The effect of raised intramammary pressure on mammary function in the goat in relation to cessation of lactation, J. Physiol. (Lond.) 301 (1980) 415-428.

[74] Peaker M., Blatchford D.R., Distribution of milk secretion in the goat mammary gland and its relation to the rate and control of milk secretion, J. Dairy Res. 55 (1988) 41-48.

[75] Pearl S.L., Downey H.F., Lepper T.L., Intramammary pressure and mammary blood flow in lactating goats, J. Dairy Sci. 56 (1973) 1319-1323.

[76] Pearson R.E., Fulton L.A., Thompson P.D., Smith J.W., Three times a day milking during the first half of lactation, J. Dairy Sci. 62 (1979) 1941-1950.

[77] Pelissier C.L., Koong L.J., Bennett L.F., Influence of milking 3 times daily on milk and fat production, J. Dairy Sci. (Suppl.) 61 (1978) 132.

[78] Pfeilsticker H.U., Bruckmaier R.M., Blum J.W., Cisternal milk in the dairy cow during lactation and after preceding teat stimulation, J. Dairy Res. 63 (1996) 509-515.

[79] Quarrie L., Addey C.V., Wilde C.J., Local control of mammary apoptosis by milk stasis, in: Intercellular Signalling in the Mammary Gland, Plenum Press, New-York, 1995, pp. 95-96.

[80] Rémond B., Boit M.P., Effects of milking three times in 2 days for 3 weeks in early lactation or in the declining phase on milk production in primiparous and multiparous dairy cows, Ann. Zootech. 46 (1997) 339-348.

[81] Reynolds M., Linzell J.L., Rasmussen F., Comparison of four methods for measuring mammary blood flow in conscious goats, Am. J. Physiol. 214 (1968) 1415-1424.

[82] Sagi R., Gorewit R.C., Wilson D.B., Role of exogenous oxytocin in eliciting milk ejection in dairy cows, J. Dairy Sci. 63 (1980) 2006-2011.

[83] Sapino A., Macri L., Tonda L., Bussolati G., Oxytocin enhances myoepithelial cell differentiation and proliferation in the mouse mammary gland, Endocrinol. 133 (1993) 838-842.

[84] Schams D., Mayer H., Prokopp A., Worstorff H., Oxytocin secretion during milking in dairy cows with regard to the variation and importance of a threshold level for milk removal, J. Endocrinol. 102 (1984) 337-343.

[85] Snowder G.D., Glimp H.A., Influence of breed, number of suckling lambs, and stage of lactation on ewe milk production and lamb growth under range conditions, J. Anim. Sci. 69 (1991) 923-930.

[86] Stelwagen K., Effect of milking frequency on mammary functioning and shape of the lactation curve, J. Dairy Sci. (Suppl.) 84 (2001) E204-E211.

[87] Stelwagen K., Knight C.H., Effect of unilateral once or twice daily milking of cows on milk yield and udder characteristics in early and late lactation, J. Dairy Res. 64 (1997) 487-494.

[88] Stelwagen K., Lacy-Hulbert S.J., Effect of milking frequency on milk somatic cell count characteristics and mammary secretory cell damage in cows, Am. J. Vet. Res. 57 (1996) 902-905.

[89] Stelwagen K., Davis S.R., Farr V.C., Prosser C.G., Sherlock R.A., Mammary epithelial cell tight junction integrity and mammary blood flow during an extended milking interval in goats, J. Dairy Sci. 77 (1994) 426-432.

[90] Swann S.W., O'Shaughnessy P.J., Birkett S.D., Wathes D.C., Porter D.G., Pickering B.T., Biosynthesis of oxytocin in the corpus luteum, FEBS Lett. 174 (1984) 262-266.

[91] Szücs E., Acs I., Ugry K., Sas M., Török I., Fodor E., Three-times-a-day milking in high productivity cow stock, Acta Agron. Hung. 37 (1988) 123-133.

[92] Tonner E., Allan G.J., Flint D.J., Hormonal control of plasmin and tissue-type plasminogen activator activity in rat milk during involution of the mammary gland, J. Endocrinol. 167 (2000) 265-273.

[93] Travers M.T., Barber M.C., Tonner E., Quarrie L., Wilde C.J., Flint D.J., The role of prolactin and growth hormone in the regulation of casein gene expression and mammary cell survival: relationships to milk synthesis and secretion, Endocrinology 137 (1996) 1530-1539.

[94] Van der Iest R., Hillerton J.E., Short-term effects of frequent milking of dairy cows, J. Dairy Res. 56 (1989) 587-592.

[95] Wakerly J.B., Clarke G., Summerlee A.J.S., Milk ejection and its control, in: Knobil E., Neill J.D. (Eds.), The Physiology of Reproduction, Raven Press, Ltd., New York, 1994, pp. 1131-1171.

[96] Wathes D.C., Swann R.W., Is oxytocin an ovarian hormone?, Nature 297 (1982) 225-227.

[97] Watkins W.B., Immunohistochemical localization of neurophysin and oxytocin in the sheep corpora lutea, Neuropeptides 4 (1983) 51-54.

[98] Wheelock J.V., Smith A., Dood F.N., The effect of a temporary suspension of milking in mid lactation on milk secretion after the resumption of milking and in the following lactation, J. Dairy Res. 34 (1967) 151-161. 
[99] Wilde C.J., Calvert D.T., Daly A., Peaker M., The effect of goat milk fractions on synthesis of milk constituents by rabbit mammary explants and on milk yield in vivo, Biochem. J. 242 (1987) 285-288.

[100] Wilde C.J., Addey C.V., Casey M.J., Blatchford D.R., Peaker M., Feed-back inhibition of milk secretion: the effect of a fraction of goat milk on milk yield and composition, Q. J. Exp. Physiol. 73 (1988) 391-397.

[101] Wilde C.J., Addey C.V., Knight C.H., Regulation of intracellular casein degradation by secreted milk proteins, Biochim. Biophys. Acta 992 (1989) 315-319.

[102] Wilde C.J., Addey C.V., Boddy L.M., Peaker M., Autocrine regulation of milk secretion by a protein in milk, Biochem. J. 305 (1995) 51-58.

[103] Young W.S., Shepard E., Amico J., Hennighausen L., Wagner K.U., LaMarca M.E., McKinney C., Ginns E.I., Deficiency in mouse oxytocin prevents milk ejection, but not fertility or parturition, J. Neuroendocrinol. 8 (1996) 847-853.

[104] Zaks M.G., The motor apparatus of the mammary gland, Oliver et Boyd, Edinburg, 1962. 